\title{
Neutrotoxic effects of fructose administration in rat brain: implications for fructosemia
}

\author{
ERNESTO A. MACONGONDE ${ }^{1}$, NAITHAN L.F. COSTA ${ }^{1}$, BRUNA K. FERREIRA ${ }^{1}$, MAIRIS S. BIELLA ${ }^{1}$, \\ MARISA J.S. FREDERICO ${ }^{2}$, MARCOS R. DE OLIVEIRA ${ }^{3}$, SILVIO ÁVILA JÚNIOR ${ }^{1}$, FÁTIMA \\ R.M.B. SILVA ${ }^{2}$, GUSTAVO C. FERREIRA ${ }^{4}$, EMILIO L. STRECK ${ }^{5}$ and PATRÍCIA F. SCHUCK ${ }^{1}$ \\ ${ }^{1}$ Laboratório de Erros Inatos do Metabolismo, Unidade Acadêmica de Ciências da Saúde, \\ Universidade do Extremo Sul Catarinense, Av. Universitária, 1105, bloco S, sala 6, 88806-000 Criciúma, SC, Brasil \\ ${ }^{2}$ Laboratório de Hormônios e Transdução de Sinais, Departamento de Bioquímica, \\ Universidade Federal de Santa Catarina, Campus Universitário, Córrego Grande, 88037-100 Florianópolis, SC, Brasil \\ ${ }^{3}$ Departamento de Química, Instituto de Ciências Exatas e da Terra, Universidade Federal de Mato Grosso, \\ Av. Fernando Correa da Costa, 2367, Boa Esperança, 78060-900 Cuiabá, MT, Brasil \\ ${ }^{4}$ Laboratório de Bioenergética, Instituto de Bioquímica Médica Leopoldo de Meis, Universidade Federal do Rio de Janeiro, \\ Av. Carlos Chagas Filho, 373, Cidade Universitária, Ilha do Fundão, 21941-902 Rio de Janeiro, RJ, Brasil \\ ${ }^{5}$ Laboratório de Bioenergética, Unidade Acadêmica de Ciências da Saúde, Universidade do Extremo Sul Catarinense, \\ Av. Universitária, 1105, bloco S, sala 6, 88806-000 Criciúma, SC, Brasil
}

Manuscript received on December 23, 2014; accepted for publication on May 13, 2015

\begin{abstract}
Fructose accumulates in tissue and body fluids of patients affected by hereditary fructose intolerance (HFI), a disorder caused by the deficiency of aldolase B. We investigated the effect of acute fructose administration on the biochemical profile and on the activities of the Krebs cycle enzymes in the cerebral cortex of young rats. Rats received a subcutaneous injection of $\mathrm{NaCl}(0.9 \%$; control group) or fructose solution ( $5 \mu \mathrm{mol} / \mathrm{g}$; treated group). Twelve or $24 \mathrm{~h}$ after the administration, the animals were euthanized and the cerebral cortices were isolated. Peripheral blood (to obtain the serum) and cerebral spinal fluid (CSF) from the animals were also collected. It was observed that albumin levels were decreased and cholesterol levels were increased in CSF of animals $12 \mathrm{~h}$ after the administration of fructose. In addition, serum lactate levels were increased $12 \mathrm{~h}$ after the administration, as compared to control group. Furthermore, malate dehydrogenase activity was increased in cerebral cortex from treated group $24 \mathrm{~h}$ after the administration of this carbohydrate. Herein we demonstrate that fructose administration alters biochemical parameters in CSF and serum and bioenergetics parameters in the cerebral cortex. These findings indicate a possible role of fructose on brain alterations found in HFI patients.
\end{abstract}

Key words: brain damage, fructose, fructosemia, hereditary fructose intolerance, Krebs cycle, metabolism.

\section{INTRODUCTION}

Fructose ( $\beta$-D-fructofuranose) is a glucose epimer widely found in food, especially fruits and honey (Hardinge et al. 1965, Somogyi and Trautner 1974).

Correspondence to: Patrícia Fernanda Schuck

E-mail: patricia.schuck@pq.cnpq.br
There are several studies showing toxic effect of fructose per se (Yokozawa et al. 2008, Fan et al. 2014, Yeh et al. 2014) or by inducing glyoxal and methylglyoxal formation (Marufetal.2015). Recent studies have specifically described neurotoxicity elicited by this carbohydrate, inducing oxidative 
stress, inhibiting acetylcholinesterase activity and affecting brain mitochondrial function (Guimarães et al. 2014, Lopes et al. 2014, Mortensen et al. 2014).

Increased levels of fructose are found in hereditary fructose intolerance (HFI) (Steinmann et al. 2001). HFI (OMIM 229600) is an autosomal recessive inborn error of fructose metabolism caused by the deficiency of the enzyme fructose1-fosfato aldolase (EC 4.1.2.7.), also known as aldolase B. This enzyme is present in liver, kidney, and small intestine (Van den Berghe 1986). The deficiency leads to the accumulation of fructose in biological fluids and tissues of patients (Steinmann et al. 2001). The onset of signs and symptoms coincides with the introduction of fruits in the diet. Continuous exposure of patients affected by HFI to fructose during infancy may result in liver damage, mental retardation, and even death (Gopher et al. 1990, Steinmann et al. 2001). Metabolic sequellae includes hypoglycemia, hyperuricemia, hypophosphatemia, hyperlactatemia, and metabolic acidosis (Cornblath et al. 1963, Perheetupa et al. 1972, Froesch 1976, 1978).

Considering that the identification of pathophysiological mechanisms of cerebral manifestations has not emerged yet, studies evaluating the effect of high levels of fructose in the brain are necessary. Previous studies from our group described an animal model of fructosemia induced chemically by administrating fructose acutely to rats (Monteiro et al. 2012, Lopes et al. 2014). By using this experimental model, we evaluated the biochemical profile in cerebral spinal fluid (CSF) and serum and the activities of Krebs cycle enzymes in the cerebral cortex of young rats.

\section{MATERIALS AND METHODS}

FRUCTOSE SOLUTION

Fructose (Sigma-Aldrich; St. Louis, MO, USA) was dissolved in saline solution ( $\mathrm{NaCl} 0.9 \%)$ always on the day of the experiment and its $\mathrm{pH}$ was adjusted to 7.4 .
ANIMALS

Twenty-four 30-day-old male Wistar rats obtained from the Central Animal House of Universidade do Extremo Sul Catarinense were used. Rats were kept with dams until weaning at 21 days of age. The animals had free access to water and to a standard commercial chow and were maintained on a 12:12 h light/dark cycle in an air-conditioned constant temperature $\left(22 \pm 1{ }^{\circ} \mathrm{C}\right)$ colony room. The Guide for the Care and Use of Laboratory Animals (National Research Council, 2011) and the "EC Directive 86/609/EEC" were followed in all experiments. All efforts were made to minimize the number of animals used and their suffering. This study was approved by the Local Ethical Committee on Animal Use for Research under the protocol 076/2013-2.

\section{FRUCTOSE ADMINISTRATION AND TISSUES PREPARATION}

The animals were divided into two groups: control group, which received a single subcutaneous injection of vehicle ( $0.9 \%$ sodium chloride), and fructose group, which received a single subcutaneous injection of fructose $(5 \mu \mathrm{mol} / \mathrm{g}$ body weight or $0.9 \mathrm{mg} / \mathrm{g}$ of body weight), according to Monteiro et al. (2012) and Lopes et al. (2014).

Twelve or $24 \mathrm{~h}$ after the administration, the animals were euthanized by decapitation without anesthesia, and the brains, skeletal muscle and liver were rapidly excised on a Petri dish placed on ice and cerebral cortices were isolated. Peripheral blood was also collected in order to obtain the serum by centrifuging at 10,000 rpm for $10 \mathrm{~min}$. CSF was collected from cisterna magna with a needle number 23. After collected, CSF was centrifuged in order to precipitate any possible blood contamination. Cerebral cortices were weighed and homogenized with SETH buffer, pH 7.4 (250 mM sucrose, $2 \mathrm{mM}$ EDTA, $10 \mathrm{mM}$ Trizma base, $50 \mathrm{IU} / \mathrm{ml}$ heparin). The homogenates were centrifuged at $800 \times g$ for $10 \mathrm{~min}$ at $4{ }^{\circ} \mathrm{C}$, and the supernatants were kept at $-80{ }^{\circ} \mathrm{C}$ until the determination of the enzyme activities. Skeletal muscle and liver were homogenized with 
$33 \% \mathrm{KOH}$ and the homogenates were used for glycogen content.

DETERMINATION OF GLUCOSE, CHOLESTEROL, ALBUMIN, LACTATE DEHYDROGENASE, AND LACTATE LEVELS

Glucose, cholesterol, and albumin were measured in CSF of the animals and lactate dehydrogenase (LDH; EC 1.1.1.27) and lactate levels were measured in serum samples from rats submitted to the animal model by using commercial kits (Labtest, Lagoa Santa, MG, Brazil), according to the instructions of the manufacturer.

\section{DETERMINATION OF GLYCOGEN CONTENT}

Glycogen content was measured in skeletal muscle and liver according to Krisman (1962), with slight modifications. The homogenates were boiled at $100{ }^{\circ} \mathrm{C}$ for $20 \mathrm{~min}$, with stirring. After cooling, $96 \%$ ethanol was added to the samples, and they were heated again to boiling and further cooling in an ice bath to precipitate the glycogen content. The homogenates were centrifuged at $1,300 \mathrm{x} g$ for $15 \mathrm{~min}$. The supernatant was then discarded and the pellets were neutralized with saturated $\mathrm{NH}_{4} \mathrm{Cl}$. The pellet was heated to $100{ }^{\circ} \mathrm{C}$ for 5 min and solubilized in water. Glycogen content was determined by treatment with iodine reagent and the absorbance was measured at $460 \mathrm{~nm}$. The results are expressed as mg of glycogen/g of tissue.

\section{KREBS CYCLE ENZYME ACTIVITIES}

\section{Citrate synthase activity}

Citrate synthase (CS; EC 2.3.3.1) activity was measured according to Srere (1969). CS was assayed in a medium containing $0.1 \mathrm{mM} \mathrm{5,5}$ "'-dithiobis(2-nitrobenzoate) (DTNB), $0.2 \mathrm{mM}$ oxaloacetic acid, $0.1 \%$ triton $\mathrm{X}-100,0.1 \mathrm{mM}$ acetyl-CoA, and $100 \mathrm{mM}$ Tris-HCl, $\mathrm{pH}$ 8.0, and aliquots of cerebral cortex homogenates ( $3 \mathrm{mg}$ protein). The activity was determined as DTNB reduction at $\lambda=412 \mathrm{~nm}$. The results are expressed as nmol TNB . $\min ^{-1}$. mg protein $^{-1}$.
Isocitrate dehydrogenase activity

Isocitrate dehydrogenase (IDH; EC 1.1.1.41) activity was determined in $33 \mathrm{mM}$ Tris buffer, $\mathrm{pH}$ 7.4, containing $33 \mathrm{mM}$ Tris- $\mathrm{HCl}, 10 \mu \mathrm{M}$ rotenone, $1.2 \mathrm{mM} \mathrm{MnCl}_{2}, 0.67 \mathrm{mM}$ ADP, $0.1 \%$ Triton $\mathrm{X}-100,0.3 \mathrm{mM}$ NAD, cortical homogenates (75 $\mathrm{mg}$ protein), and $5 \mathrm{mM}$ isocitrate (Plaut 1969). NAD reduction at $\lambda=340-400 \mathrm{~nm}$ was followed and the results are expressed as nmol NADH . $\min ^{-1}$. mg protein ${ }^{-1}$.

\section{Succinate dehydrogenase activity}

Succinate dehydrogenase (SDH; EC 1.3.99.1) activity was determined according to the method of Fischer et al. (1985), by following the decrease in absorbance, due to the reduction of 2,6-dichloroindophenol at $600 \mathrm{~nm}$. The results are expressed as nmol. $\min ^{-1}$. mg protein ${ }^{-1}$.

\section{Fumarase activity}

Fumarase (EC 4.2.1.2) activity was assayed in 100 $\mathrm{mM}$ sodium phosphate buffer, $\mathrm{pH} 7.3$, containing $50 \mathrm{mM}$ L-malate. The activity was determined by measuring the increase of absorbance at $\lambda=250$ nm (O'Hare and Doonan 1985). The results are expressed as nmol fumarate. $\mathrm{min}^{-1}$. $\mathrm{mg}$ protein ${ }^{-1}$.

\section{Malate dehydrogenase activity}

Malate dehydrogenase (MDH; EC 1.1.1.37) activity was measured according to Kitto (1969), in a buffer containing $10 \mu \mathrm{M}$ rotenone, $0.3 \%$ Tween 20, $0.14 \mathrm{mM}$ NADH, $0.30 \mathrm{mM}$ oxalacetate, $50 \mathrm{mM}$

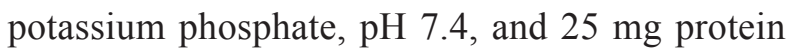
from cerebral cortex preparations. MDH activity was determined by following the reduction of $\mathrm{NADH}$ absorbance at $\lambda=340-400 \mathrm{~nm}$. The results are expressed as nmol NADH . min $^{-1}$. $\mathrm{mg}_{\text {protein }}{ }^{-1}$. 


\section{PROTEIN QUANTIFICATION}

Protein concentrations were measured by the method of Lowry et al. (1951), using bovine serum albumin as standard.

\section{STATISTICAL ANALYSES}

Results are presented as mean \pm standard error of mean. Assays were performed in duplicate or triplicate and the mean or median was used for statistical analysis. Results were analyzed by Student's $t$ test for independent samples. Differences between groups were rated significant at $p<0.05$. All analyses were carried out in an IBM-compatible PC computer using the Statistical Package for the Social Sciences (SPSS) software 16.0.

\section{RESULTS}

We first investigated biochemical parameters in CSF of rats submitted to acute fructose administration. It was observed that total cholesterol levels were markedly increased $12 \mathrm{~h}$ after fructose administration $[t(9)=-4.64 ; p=0.001]$. In contrast, albumin levels were decreased $12 \mathrm{~h}$ after the administration of this carbohydrate $[t(6)=2.14$; $p<0.05]$. It was not identified any difference of both total cholesterol and albumin levels in CSF between groups $24 \mathrm{~h}$ after fructose administration. Glucose levels were not altered either $12 \mathrm{~h}$ or $24 \mathrm{~h}$ in CSF after fructose administration (Table I).

The influence of acute fructose administration on LDH and lactate levels in serum of rats was also investigated and it was observed that LDH was not altered either $12 \mathrm{~h}$ or $24 \mathrm{~h}$ after administration. On the other hand, lactate serum levels were increased $12 \mathrm{~h}$ after fructose administration, as compared to control group $[t(8)=-2.32 ; p<0.05]$. In contrast, lactate levels were decreased $24 \mathrm{~h}$ after fructose administration, although not significantly $[t(8)=$ $2.31 ; p=0.066$ ] (Table II).

Furthermore, we determined glycogen content in skeletal muscle and liver of rats euthanized 12 or $24 \mathrm{~h}$ after fructose administrations. Fructose administration did not alter this parameter after 12 hours or $24 \mathrm{~h}$ in skeletal muscle and in liver (Table III).

Finally, we investigated the in vivo effect of fructose on Krebs cycle enzymes activities $24 \mathrm{~h}$ after the administration of this carbohydrate. It was demonstrated that MDH activity was increased in cerebral cortices of animals submitted to the animal model of fructosemia, as compared to controls $[t(10)=-2.49 ; p<0.05]$. On the other hand, CS, $\mathrm{IDH}, \mathrm{SDH}$, and fumarase activities were not altered by fructose administration (Fig. 1).

\section{DISCUSSION}

Some patients affected by HFI may present neurological impairment (Labrune et al. 1990, Steinmann et al. 2001), but the mechanisms underlying these symptoms are not well understood. In the present study, we demonstrated the effects of the acute administration of fructose, the main metabolite accumulated in HIF, on cerebral metabolism of rats. The animal model used reflects the characteristic findings of fructosemic patients during metabolic crises. This model allowed us

TABLE I

Glucose, cholesterol, and albumin levels in cerebral spinal fluid of animals submitted to an animal model of fructosemia.

\begin{tabular}{ccc}
\hline & Control & Fructose \\
\hline \multicolumn{2}{c}{$\mathbf{1 2} \mathbf{~ h}$} \\
\hline Glucose & $69.5 \pm 4.96$ & $59.42 \pm 6.84$ \\
Cholesterol & $6.88 \pm 0.98$ & $13.5 \pm 1.00^{* * *}$ \\
Albumin & $0.31 \pm 0.06$ & $0.18 \pm 0.01^{*}$ \\
\hline \multicolumn{2}{c}{$\mathbf{2 4} \mathbf{~ h}$} \\
\hline Glucose & $34.9 \pm 7.05$ & $36.3 \pm 4.32$ \\
Cholesterol & $26.4 \pm 0.92$ & $26.88 \pm 1.09$ \\
Albumin & $0.07 \pm 0.006$ & $0.09 \pm 0.03$ \\
\hline
\end{tabular}

Values are mean \pm standard error of mean for six independent experiments (animals) per group performed in duplicate. Data were expressed as mg/dL. ${ }^{*} p<0.05 ; * * * p<0.001$ compared to control (Student's $t$ Test). 
to investigate the biochemical alterations that occur after a single ingestion of high fructose concentrations, when fructose levels in plasma and tissues rise drastically shortly after the increased ingestion of fructose. Previous works using animal models of fructosemia also used fructose injections (Klein et al. 1946, Phillips and Yu 1974), but at

TABLE II

Lactate dehydrogenase (LDH) and lactate levels in serum of animals submitted to an animal model of fructosemia.

\begin{tabular}{ccc}
\hline & Control & Fructose \\
\hline LDH & $494 \pm 40.1$ & $448 \pm 73.2$ \\
Lactate & $12.1 \pm 0.97$ & $21.7 \pm 4.00^{*}$ \\
\hline \multicolumn{3}{c}{$\mathbf{2 4} \mathbf{~ h}$} \\
\hline LDH & $113 \pm 2.86$ & $119 \pm 2.94$ \\
Lactate & $18.8 \pm 2.78$ & $12.3 \pm 0.44$ \\
\hline
\end{tabular}

Values are mean \pm standard error of mean for six independent experiments (animals) per group performed in duplicate. Data were expressed as UI/dL for $\mathrm{LDH}$ and $\mathrm{mg} / \mathrm{dL}$ for lactate levels. $* p<0.05$ compared to control group (Student's $t$ Test). different doses. Klein et al. (1946) described that brain fructose concentrations were 7 times lower than the plasma levels in cats. It was also considered that fructosemic patients with a fructose-free diet present plasma concentrations of $0.14 \mathrm{mg} / \mathrm{mL}$, but the levels of this sugar can reach up to 10 times more after its ingestion (Levin et al. 1963).

TABLE III

Glycogen content in skeletal muscle and liver of animals 24 hours after fructose administration.

\begin{tabular}{ccc}
\hline & Control & Fructose \\
\hline Skeletal Muscle & $0.39 \pm 0.05$ & $0.41 \pm 0.6$ \\
Liver & $0.35 \pm 0.04$ & $0.33 \pm 0.06$ \\
\hline
\end{tabular}

Values are mean \pm standard error of mean for six independent experiments (animals) per group performed in duplicate. Data were expressed as $\mathrm{mg}$ of glycogen/g of tissue. No difference between groups were detected (Student's $t$ Test). (a)

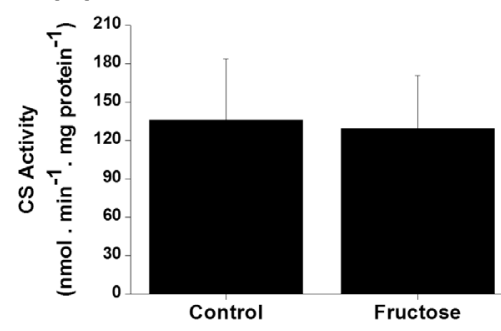

(d)

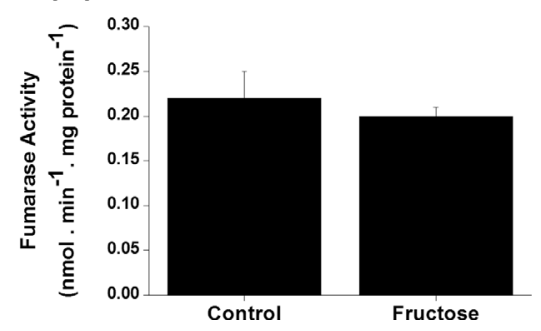

(b)



(c)

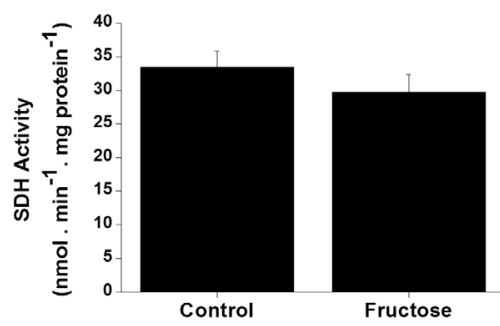

Figure 1 - Effects of acute fructose administration on the activities of Krebs cycle enzymes citrate synthase (CS) (a), isocitrate dehydrogenase (IDH) (b), succinate dehydrogenase (SDH) (c), fumarase (d), and malate dehydrogenase (MDH) (e) in rat cerebral cortex of rats $24 \mathrm{~h}$ after the administration. Values are means \pm standard deviation for five to six independent experiments per group performed in duplicate and are expressed as nmol. $\min ^{-1} . \mathrm{mg}$ protein ${ }^{-1} .{ }^{*} p<0.05$ compared to controls (Student's $t$ test). 
Initially, we evaluated the biochemical profile of CSF from animals submitted to an experimental model of fructosemia 12 and $24 \mathrm{~h}$ after acute fructose administration. It was observed that glucose levels were not altered in CSF of fructosemic animals $12 \mathrm{~h}$ nor $24 \mathrm{~h}$ after the administration of this carbohydrate. On the other hand, CSF albumin levels were decreased $12 \mathrm{~h}$ after the administration of fructose in animals as compared to control group, and these levels were restored $24 \mathrm{~h}$ after the administration. A decrease of this protein levels cannot be attributed to malnutrition, since CSF albumin levels, different from serum albumin, are not related to nutritional status of the organism. In this context, Wade and colleagues described that in fasting conditions, rat CSF albumin levels remain unaltered, while serum levels are decreased (Wade et al. 1988). Furthermore, Monteiro et al. (2012) showed that serum albumin levels were not altered $12 \mathrm{~h}$ or $24 \mathrm{~h}$ after acute fructose administration. In this scenario, decreased prealbumin levels in CSF were also observed in patients affected by multiple sclerosis and Alzheimer's disease (Hybelová et al. 2009, Ribeiro et al. 2012). Diminished albumin levels could also be attributed to proteolysis, which may occur due to the lack of energy substrates such as glucose, in order to provide carbons to oxidative reactions to further synthesize ATP. However, this possibility is unlikely, since glucose levels in CSF were not altered in our animal model. More studies should be conducted in order to clarify this effect.

In addition, cholesterol levels were increased in CSF from animals receiving fructose $12 \mathrm{~h}$ after the administration. It is widely reported that fructose stimulates lipid synthesis including cholesterol in liver (Hwang et al. 1987, Hulman and Falkner 1994, Laville and Nazare 2009, Tran et al. 2009, Chou et al. 2011), but it is still to be unraveled in the brain. Recently, cholesterol levels in CSF have been suggested as a marker of brain health since this parameter was found increased in cognitive impairment and Alzheimer's disease and the levels of cholesterol are associated with the progression of cognitive dysfunction (Leoni et al.
2013, Trushina et al. 2013). Increased cholesterol levels in CSF were also observed in patients affected by cerebrotendinous xanthomatosis (Salen et al. 1987) and in multiple sclerosis (van de Kraats et al. 2014). It is possible that increased cholesterol levels provoked by fructose administration could be related to the impaired cognitive function found in rats with high fructose intake (Cao et al. 2007, Stranahan et al. 2008, Ross et al. 2009, Hsu et al. 2015).

Our next step was to evaluate the effects of acute fructose administration on energy status in serum from animals and it was observed that LDH activity in animals receiving fructose did not differ from control groups. On the other hand, acute fructose administration increased serum lactate levels of fructosemic animals $12 \mathrm{~h}$ after the injection. Interestingly, Monteiro et al. (2012) showed that serum glucose levels were unaltered in the same animal model and time frames used in the present study. Increased lactate levels without glucose levels alterations suggest that glycolysis was not affected by fructose administration, but possibly reflect mitochondrial dysfunction. In line with previous data showing no alteration in serum glucose levels (Monteiro et al. 2012), no alteration of glycogen content in liver and skeletal muscle (tissues rich in this polysaccharide) of rats submitted to animal model of fructosemia in the present study was observed, corroborating the idea that glucose metabolism is not impaired in this experimental model.

Considering that increased serum lactate levels suggest mitochondrial dysfunction, we then evaluated the effect of acute fructose administration on Krebs cycle enzyme activities in homogenates from cerebral cortices of rats 24 $\mathrm{h}$ after the administration of this monosaccharide. It was observed that MDH activity was increased in this tissue, while CS, IDH, SDH, and fumarase activities were not altered in cerebral cortices of animals receiving fructose administration in comparison to control group. 
It has been shown that MDH activity is increased in the brain of patients affected by schizophrenia (Bubber et al. 2011) and Alzheimer disease post mortem in regions affected by oxidative stress (Op den Velde and Stam 1976, Bubber et al. 2005). Shi and Gibson (2011) demonstrated that $\mathrm{H}_{2} \mathrm{O}_{2}$ increased $\mathrm{MDH}$ activity in hippocampal cell lines by increasing mRNA levels of the gene that expresses this enzyme. In this context, recently Lopes et al. (2014) demonstrated that acute fructose administration induced oxidative damage to lipids and proteins and altered enzyme antioxidant defenses in cerebral cortex. Thus, it is tempting to speculate that increased MDH activity caused by acute fructose administration might be due to oxidative stress.

The implication of increased MDH activity is unknown. MDH is the last step of Krebs cycle, restoring oxaloacetate levels to allow the continuous oxidation of acetyl-CoA in the mitochondria. During this reaction, reducing NADH equivalents are released, which are oxidized at the respiratory chain complex I (Dupourque and Kun 1969). MDH also participates on malateaspartate shuttle, translocating electrons from cytosolic NADH to mitochondrial matrix to be oxidized at respiratory chain, since mitochondrial membranes are impermeable to this coenzyme. Increased MDH activity without a parallel increase of the other enzyme activities of the cycle could lead to an increase of $\mathrm{NADH} / \mathrm{NAD}^{+}$ratio, which could ultimately block the cycle, since $\mathrm{NAD}^{+}$is also necessary for isocitrate dehydrogenase and alpha-ketoglutarate dehydrogenase activities. This effect on bioenergetics could also collaborate to the impairment of cognitive function, synaptic plasticity, dendritic spine density, and neurogenesis in the hippocampus, as well as neuronal loss caused by fructose (Cao et al. 2007, Stranahan et al. 2008, Ross et al. 2009, Stephan et al. 2010, Van der Borght et al. 2011, Rafati et al. 2013).

Important differences in biochemical parameters after $12 \mathrm{~h}$ and $24 \mathrm{~h}$ of fructose exposure were observed. At present we cannot ascertain the exact explanation for these differences. In this scenario, more studies should be carried out in order to clarify and better understand the present data. Additional study is also required regarding the nutritional status of rats receiving fructose acutely and chronically.

Concluding, we herein demonstrated that fructose exerts neurotoxic effects in cerebral cortex of rats submitted to an animal model of fructosemia. These data suggest that fructose toxicity might play a role in the neurological symptoms observed in patients affected by HIF.

\section{ACKNOWLEDGMENTS}

This study was funded with grants from Conselho Nacional de Desenvolvimento Científico e Tecnológico (CNPq), Universidade do Extremo Sul Catarinense (UNESC) and Núcleo de Excelência em Neurociências de Santa Catarina (NENASC Project/PRONEX).

\section{RESUMO}

Frutose se acumula em tecidos e líquidos corporais de pacientes afetados por intolerância hereditária à frutose (HFI), doença causada pela deficiência da aldolase B. Nós investigamos o efeito da administração aguda de frutose sobre o perfil bioquímico e as atividades das enzimas do ciclo de Krebs em córtex cerebral de ratos jovens. Os ratos receberam uma administração subcutânea de $\mathrm{NaCl}(0,9$ \%; grupo controle) ou solução de frutose $(5 \mu \mathrm{mol} / \mathrm{g}$; grupo tratado). Doze ou 24 horas após a administração, os animais sofreram eutanásia e os córtices cerebrais foram isolados. Também foram coletados sangue periférico (para obtenção de soro) e líquido cefalorraquidiano (LCR) dos animais. Foi observado que os níveis de albumina diminuíram e os níveis de colesterol aumentaram no LCR dos animais 12 horas após a administração de frutose. Adicionalmente, os níveis séricos de lactato aumentaram $12 \mathrm{~h}$ após a administração, em comparação como grupo controle. Além disso, a atividade da malato desidrogenase aumentou no córtex cerebral do grupo tratado $24 \mathrm{~h}$ após administração deste carboidrato. No presente trabalho, demonstramos que a administração de frutose altera 
parâmetros bioquímicos em LCR e soro, bem como parâmetros bioenergéticos em córtex cerebral. Tais achados sugerem um papel para a frutose nas alterações cerebrais encontradas em pacientes com HFI.

Palavras-chave: dano cerebral, frutose, frutosemia, intolerância hereditária à frutose, ciclo de Krebs, metabolismo.

\section{REFERENCES}

Bubber P, Haroutunian V, Fisch G, Blass JP AND GIBSON GE. 2005. Mitochondrial abnormalities in Alzheimer brain: mechanistic implications. Ann Neurol 57: 695-703.

BUBber P, HARTOUNIAN V, GIBSON GE AND BLASS JP. 2011. Abnormalities in the tricarboxylic acid (TCA) cycle in the brains of schizophrenia patients. Eur Neuropsychopharmacol 21: 254-260.

CAO D, LU H, LEWIS TL AND LI L. 2007. Intake of sucrosesweetened water induces insulin resistance and exacerbates memory deficits and amyloidosis in a transgenic mouse model of Alzheimer disease. J Biol Chem 282: 36275 36282 .

CHOU CL, LAI YH, LIN TY, LEE TJ AND FANG TC. 2011. Aliskiren prevents and ameliorates metabolic syndrome in fructose-fed rats. Arch Med Sci 7: 882-888.

CORNBLATH M, ROSENTHAL IM, REISNER SH, WYBREGT SH AND CRANE RK. 1963. Hereditary fructose intolerance. N Eng J Med 269: 1271-1278.

DUPOURQUE D AND KUN E. 1969. Malate dehydrogenases of ox kidney 2. Two substrate kinetic and inhibition analyses. Eur J Biochem 7: 247-252.

FAN CY, WANG MX, GE CX, WANG X, LI JM AND KONG LD. 2014. Betaine supplementation protects against highfructose-induced renal injury in rats. J Nutr Biochem 25: 353-362.

FISCHER JC, RUITENBEEK W, BERDEN JA, TRIJBELS JM, VEERKAMP JH, STADHOUdERS AM, SENGERS RC AND JANSSEN AJ. 1985. Differential investigation of the capacity of succinate oxidation in human skeletal muscle. Clin Chim Acta 153: 23-26.

FROESCH ER. 1976. Disorders of fructose metabolism. Clin Endocrinol Metab 5: 599-611.

FROESCH ER. 1978. Essential fructosuria, hereditary fructose intolerance, and fructose-1-6-diphosphatase deficiency. In: Stanbury JB, Wyngaarden JB and Fredrickson DS (Eds), Metabolic basis of inherited disease, New York: McGrawHill, New York, USA, p. 121.

GOPHER A, VAISMAN N, MANDEL H AND LAPIDOT A. 1990. Determination of fructose metabolic pathways in normal and fructose-intolerant children: a 13C NMR study using $\left[\mathrm{U}-{ }^{13} \mathrm{C}\right]$ fructose. Proc Natl Acad Sci USA 87: 5449-5453.
Guimarães CA, Biella MS, Lopes A, Deroza PF, OLIVEIRA MB, MACAN TP, STRECK EL, FERREIRA GC, ZUGNO AI AND SCHUCK PF. 2014. In vivo and in vitro effects of fructose on rat brain acetylcholinesterase activity: an ontogenetic study. An Acad Bras Cienc 86: 1919-1926.

HARDINGE MG, SWARNER JB AND CROOKS H. 1965. Carbohydrates in foods. J Am Diet Assoc 46: 197.

HSU TM, KONANUR VR, TAING L, USUI R, KAYSER BD, GORAN MI AND KANOSKI SE. 2015. Effects of sucrose and high fructose corn syrup consumption on spatial memory function and hippocampal neuroinflammation in adolescent rats. Hippocampus 25(2): 227-239.

HULMAN S AND FALKNER B. 1994. The effect of excess dietary sucrose on growth, blood pressure, and metabolism in developing Sprague-Dawley rats. Pediatr Res 36: 95-101.

HWANG IS, Ho H, HOFFMAN BB AND REAVEN GM. 1987. Fructose-induced insulin resistance and hypertension in rats. Hypertension 10: 512-516.

Hybelová M, SVATONOVÁ J, SOBEK O, ADAM P, DOLEZIL D AND ADAM D. 2009. Cerebrospinal fluid and serum prealbumin (transthyretin) in patients with multiple sclerosis (MS): comparison of particular subgroups of MS patients. Folia Microbiol (Praha) 54: 173-176.

KITTO GB. 1969. Intra- and extramitochondrial malate dehydrogenases from chicken and tuna heart. Methods Enzymol 13: 106-116.

KLEIN JR, HURWITZ R AND OLSEN NS. 1946. Distribution of intravenously injected fructose and glucose between blood and brain. J Biol Chem 164: 509-512.

KRISMAN CR. 1962. A method for the colorimetric estimation of glycogen with iodine. Anal Biochem 4: 17-23.

LABRUne P, Chatelon S, Huguet P AND Odievre M. 1990. Unusual cerebral manifestations in hereditary fructose intolerance. Arch Neurol 47: 1243-1244.

LAVILLE M AND NAZARE JA. 2009. Diabetes, insulin resistance and sugars. Obes Rev 10: 24-33.

LEONI V, SOLOMON A, LÖVGREN-SANDBLOM A, MINTHON L, BLENNOW K, HANSSON O, WAHLUND LO, KIVIPELTO M AND BJÖRKHEM I. 2013. Diagnostic power of 24S-hydroxycholesterol in cerebrospinal fluid: candidate marker of brain health. J Alzheimers Dis 36: 739-747.

LEVIN B, OBERHOLZER VG, SNODGRASS GJ, STIMMLER L AND WILMERS MJ. 1963. Fructosaemia: an inborn error of fructose metabolism. Arch Dis Child 38: 220-230.

LOPES A, VilelA TC, TASCHETTO L, VUOLO F, PETRONILHO F, DAL-Pizzol F, STRECK EL, FERREIRA GC AND SCHUCK PF. 2014. Evaluation of the effects of fructose on oxidative stress and inflammatory parameters in rat brain. Mol Neurobiol 50: 1124-1130.

LOWRY OH, ROSEBOUGH NG, FARR AL AND RANDALL RJ. 1951. Protein measurement with the Folin phenol reagent. J Biol Chem 193: 265-275. 
MARUf AA, LIP H, WONG H AND O'BRIEN PJ. 2015. Protective effects of ferulic acid and related polyphenols against glyoxal or methylglyoxal-induced cytotoxicity and oxidative stress in isolated rat hepatocytes. Chem Biol Interact 234: 96-104.

Monteiro AA, Biella MS, Bristot SF, STreck EL, SCHUCK PF AND FERREIRA GC. 2012. Characterization of the biochemical profile in serum of young rats submitted to high concentrations of fructose. Revista Inova Saúde 1: 116-129.

MORTENSEN OH, LARSEN LH, ØRSTRUP LK, HANSEN LH, GRUNNET N AND QUISTORFF B. 2014. Developmental programming by high fructose decreases phosphorylation efficiency in aging offspring brain mitochondria, correlating with enhanced UCP5 expression. J Cereb Blood Flow Metab 34: 1205-1211.

O'HARE MC AND DoOnAN S. 1985. Purification and structural comparisons of the cytosolic and mitochondrial isoenzymes of fumarase from pig liver. Biochim Biophys Acta 827: 127-134.

Op Den Velde W AND Stam FC. 1976. Some cerebral proteins and enzyme systems in Alzheimer's presenile and senile dementia. J Am Geriatr Soc 24: 12-16.

PERHEENTUPA J, RAIVIO KO AND NIKKILA EA. 1972. Hereditary fructose intolerance. Acta Med Stand 542: 65-75.

PHILliPS MJ AND YU DT. 1974. Animal model of human disease: hereditary fructose intolerance. Am J Pathol 75: 591-594.

PLAUT GWE. 1969. Isocitrate dehydrogenase from bovine heart. In: Lowenstein JM (Ed), Methods in Enzimology, vol 13, Academic Press, New York, USA, p. 34-42.

RAFATI A, ANVARI E AND NOORAFSHAN A. 2013. High fructose solution induces neuronal loss in the nucleus of the solitary tract of rats. Folia Neuropathol 51: 214-221.

Ribeiro CA, SANTANA I, OLIVEIRA C, BALDEIRAS I, Moreira J, SARAIVA MJ AND CARDoso I. 2012. Transthyretin decrease in plasma of MCI and AD patients: investigation of mechanisms for disease modulation. Curr Alzheimer Res 9: 881-889.

Ross AP, BARTNESS TJ, MIELKE JG AND PARENT MB. 2009. A high fructose diet impairs spatial memory in male rats. Neurobiol Learn Mem 92: 410-416.

SAlEN G, BERGINER V, SHORE V, HoraK I, HoraK E, TinT GS AND SHEFER S. 1987. Increased concentrations of cholestanol and apolipoprotein B in the cerebrospinal fluid of patients with cerebrotendinous xanthomatosis: Effect of chenodeoxycholic acid. N Engl J Med 316: 1233-1238.

SHI Q AND GIBSON GE. 2011. Up-regulation of the mitochondrial malate dehydrogenase by oxidative stress is mediated by miR-743a. J Neurochem 118: 440-448.

Somogyi JC AND TRAUTNER K. 1974. Der Glukose-, Fruktose- und Saccharosegehalt verschiedener Gemüsearten. Schweiz Med Wochenschr 104: 177.
SRERE PA. 1969. Citrate synthase. Methods Enzymol 13: 3-11. STEINMANN B, GITZELMANN R AND VAN DEN BERGHE G. 2001. Disorders of Fructose Metabolism. In: Scriver CR, Beaudt AL, Sly WL and Valle D (Eds), The Metabolic and Molecular Bases of Inherited disease, New York: McGraw-Hill, New York, USA, 2001.

Stephan BC, Wells JC, BRAYNe C, Albanese E AND SIERVO M. 2010. Increased fructose intake as a risk factor for dementia. J Gerontol A Biol Sci Med Sci 65: 809-814.

Stranahan AM, Norman ED, LEE K, CUtler RG, TELLJOHANN R, EGAN JM AND MATTSON MP. 2008. Diet-induced insulin resistance impairs hippocampal synaptic plasticity and cognition in middle-aged rats. Hippocampus 18: 1085-1088.

TRAN LT, YUEN VG AND MCNEILL JH. 2009. The fructosefed rat: a review on the mechanisms of fructose-induced insulin resistance and hypertension. Mol Cell Biochem 332: $145-159$.

Trushina E, Dutta T, Persson XM, Mielke MM AND PETERSEN RC. 2013. Identification of altered metabolic pathways in plasma and CSF in mild cognitive impairment and Alzheimer's disease using metabolomics. PLoS One 8: e63644.

VAN DE KRAATS C, Killestein J, POPESCU V, RiJKers E, VRENKEN H, LÜTJOHANN D, BARKHOF F, POLMAN CH AND TEUNISSEN CE. 2014. Oxysterols and cholesterol precursors correlate to magnetic resonance imaging measures of neurodegeneration in multiple sclerosis. Mult Scler 20: 412-417.

VAN Den Berghe G. 1986. Fructose Metabolism and short-term effects on carbohydrate and purine metabolic pathways. In: Paoletti R (Ed), Metabolic Effects of Dietary Carbohydrates, vol. 21, Basel, Switzerland, Karger, p. $1-32$.

VAN DER BORGHT K, KÖHNKE R, GÖRANSSON N, DEIERBORG T, BRUNDIN P, ERLANSON-ALBERTSSON C AND LINDQVIST A. 2011. Reduced neurogenesis in the rat hippocampus following high fructose consumption. Regul Pept 167: 26-30.

Wade S, Bleiberg-Daniel F AND Le Moullac B. 1988. Rat transthyretin: effects of acute short-term food deprivation and refeeding on serum and cerebrospinal fluid concentration and on hepatic mRNA level. J Nutr 118: 199-205.

YeH TC, LIU CP, CHENG WH, CHEN BR, LU PJ, CHENG PW, Ho WY, Sun GC, LIOU JC AND TSENG CJ. 2014. Caffeine intake improves fructose-induced hypertension and insulin resistance by enhancing central insulin signaling. Hypertension 63: 535-541.

YOKOZAWA T, KIMHJ AND CHO EJ. 2008. Gravinol ameliorates high-fructose-induced metabolic syndrome through regulation of lipid metabolism and proinflammatory state in rat. J Agric Food Chem 56: 5026-5032. 